\title{
INNOVATION OF THE FEP AND SEP ACCORDING TO THE PRESENT TRENDS OF ICT EDUCATION IN PRIMARY SCHOOLS (PART 2)
}

\author{
Petr PEXA*, Jihočeská univerzita v Č. Budějovicích \\ Michaela $\check{C} \boldsymbol{A P K O V A ́}$, Jihočeská univerzita v Č. Budějovicích
}

Přijato: 22. 10. 2019 / Akceptováno: 28. 1. 2020

Typ článku: Teoretická studie

DOI: $10.5507 /$ jtie.2020.003

Abstract: The article is a continuation of the article Innovation of FEP and SEP depending on current trends in ICT teaching at primary school, which was published in JTIE in 2018 and specifies the curriculum in terms of content, typical teaching examples and programs used in connection with the published model school educational program (SEP) for teaching computer science. The article also presents a proposal of the SEP for the educational area Use of digital technologies in the educational area Man and the World of Work, whose content is the creation and processing of multimedia, website creation, raster and vector graphics.

Key words: School Education Programme, Framework Education Programme, education, ICT, primary school.

\section{INOVACE RVP A ŠVP V ZÁVISLOSTI NA AKTUÁLNÍCH TRENDECH VÝUKY ICT NA ZŠ (2. ČÁST)}

Resumé: Článek je pokračováním článku Inovace RVP a ŠVP v závislosti na aktuálních trendech výuky ICT na ZŠ, který byl publikován v JTIE v r. 2018 a konkretizuje učivo z hlediska náplně, typických výukových přikladů a využivaných programů v souvislosti s publikovaným vzorovým školním vzdělávacím programem (ŠVP) pro výuku informatiky. Článek dále představuje návrh ŠVP pro vzdělávací okruh Využití digitálních technologií ve vzdělávaci oblasti Člověk a svět práce, jehož obsahem je tvorba a zpracování multimédií, tvorba webových stránek a rastrová, vektorová či 3D grafika.

Klíčová slova: školní vzdělávací program, rámcový vzdělávací program, výuka, informační a komunikační technologie, základní škola, ŠVP, RVP, ICT.

*Autor pro korespondenci: pexa@pf.jcu.cz 


\section{1 Úvod}

Jak bylo představeno v článku Inovace RVP a ŠVP v závislosti na aktuálních trendech výuky ICT na ZŠ (Pexa; Čapková, 2018), připravila pracovní skupina z Národního ústavu pro vzdělávání v roce 2017 nový rámcový vzdělávací program (dále jen RVP) pro oblast výuky ICT na ZŠ, jehož jednotlivá témata budou muset být respektována v souvisejících konkrétních školních vzdělávacích programech (dále jen ŠVP) a zpracována podle požadavků nového RVP. Tento nový RVP byl schválen vedením MŠMT v srpnu r. 2018 a je k dispozici na webu NÚV (Národní ústav pro vzdělávání, 2018).

Nový RVP člení informatiku na čtyři části - Data, informace a modelování, Algoritmizace a programování, Informační systémy, Počítač a jeho ovládání, čímž mj. výrazně podporuje rozvoj logického myšlení žáků. Dalším pilířem je dosažení základní úrovně informační gramotnosti, respektive dovedností spojených s ovládáním počítače a dalších digitálních technologií, prací s daty a informacemi, které žáci využívají ve vzdělávání i dalších aktivitách.

Připomeňme, že kromě představení nového RVP pro oblast výuky ICT jsme ve výše zmíněném článku provedli jeho porovnání s původním RVP z r. 2005 a především publikovali vlastní vzorový ŠVP pro vzdělávací oblast Informační a komunikační technologie na 1. i 2. stupni základních škol a odpovídajících ročnících víceletých gymnázií. Tento vzorový ŠVP respektuje výraznou proměnu náplně výuky ICT a je obohacen o vzdělávací obsah, který v předešlém RVP vůbec nebyl, rovněž je obsah podrobněji popsán.

Vzorový ŠVP byl také vypracován v rámci rozvojového projektu Podpora společenství praxe jako nástroj rozvoje klíčových kompetencí (reg. č. CZ.02.3.68/0.0/0.0 /16_011/0000660), jehož hlavním řešitelem je Univerzita Palackého v Olomouci a partnery jsou Jihočeská univerzita v Českých Budějovicích a Ostravská univerzita. Jedním z požadovaných výstupů projektu jsou doporučení pro úpravu ŠVP všech zapojených škol v síti společenství praxe, bylo tedy rozhodnuto vytvořit zcela nový návrh ŠVP pro oblast výuky ICT na základních školách a odpovídajících ročnících víceletých gymnázií.

\section{Cíle a metody}

ŠVP bývají většinou obecnějšího charakteru, a to proto, aby nevznikala nutnost jejich úprav při každé drobnější výukové změně, např. ve spojitosti s využitím jiného softwaru nebo učebních pomůcek. Přesto je ale pro začínající i zkušenější učitele podstatné, jaké programy lze využívat či jaká podtémata a typy úloh zařadit do výuky. Touto problematikou jsme se v rámci výše zmíněného projektu zabývali také a v tomto novém článku konkretizujeme jednotlivé výstupy vzorového ŠVP především pro výuku aktuálních informatických témat - programování, algoritmizace a využití robotiky.

Do sféry informatiky zasahuje také vzdělávací oblast Člověk a svět práce, resp. jeden z jeho vzdělávací obsahů - Využití digitálních technologií, který prohlubuje teoretické znalosti i praktické dovednosti v tomto odvětví. Zabývá se druhy digitální techniky, způsobem přenosu informací, využitím programů při archivaci nebo úpravě dat a také bezpečností při jejím využívání (MŠMT, 2018).

Jelikož je množství informatických témat daleko rozsáhlejší než bylo doposud a některá aktuální témata v novém RVP obsažená nejsou, rozhodli jsme se vytvořit v další fázi i návrh ŠVP pro vzdělávací okruh Využití digitálních technologií (vzdělávací oblasti Člověk a svět práce), naplněný zejména tvorbou a zpracováním multimédií, tvorbou webových stránek a rastrovou, vektorovou či 3D grafikou. Návrh předpokládá výuku ve dvou ročních 
2. stupně s časovou dotací 0,5 hodiny týdně, která může být dotována $\mathrm{z}$ disponibilních hodin.

Cílem tohoto článku je tedy nabídnout vyučujícím konkretizaci učiva z hlediska náplně, typických výukových př́kladů a využívaných programů a dále představit návrh vzorového ŠVP pro výuku vzdělávacího okruhu Využití digitálních technologií vzdělávací oblasti Člověk a svět práce na 2 . stupni základních škol a víceletých gymnáziích.

Použité metody: analýza kurikulárních dokumentů, komparace kurikulárních dokumentů.

\section{Konkretizace učiva pro realizaci výuky podle vzorového ŠVP}

Následující kapitola konkretizuje učivo uvedené v článku Inovace RVP a ŠVP v závislosti na aktuálních trendech výuky ICT na ZŠ (Pexa; Čapková, 2018) z hlediska náplně, typických výukových př́kladů a využívaných programů.

\section{Data, informace a modelování}

\section{První stupeň}

- Uvede príklady dat, která ho obklopují a která mu mohou pomoci lépe se rozhodnout; vyslovuje odpovědi na základě dat.

Žáci rozlišují různou podobu dat, např. textová, grafická, zvuková, apod. V konkrétních situacích pak (např. př̌i svém vzdělávání) využívají nejvíce objasňující druhy dat, např. obrázek vystihuje vzhled zviŕete, video jeho chování, audio jeho přirozený zvuk, text popisuje způsob života.

Žáci se dozvídají o různých zdrojích dat, např. noviny, televize nebo internet. V této souvislosti konkrétní zdroje posuzují z hlediska rychlosti, věrohodnosti či důležitosti poskytnutých informací. Na konkrétní otázky odpovídají právě pomocí dat, které získali prostřednictvím různých informačních kanálů.

- Přri digitalizaci dat rozlišuje text, obrázek, video a audio; vybere nejvhodnější formu a výběr zdůvodní.

Žáci využívají různé druhy dat podle účelu, ke kterému mají být využity (text, obrázek, video, zvuk). Rozlišují klady a zápory využití různých druhů, např. lineární zobrazení textu oproti celistvému a okamžitému dojmu z obrázku.

- Vlastními slovy popíše konkrétní situaci, určí, co k ní již ví a znázorní ji.

Díky myšlenkovým a mentálním mapám lze rozebírat různé situace, se kterými se žáci setkávají v běžném životě, např. co vše je třeba $\mathrm{k}$ uvaření čaje, o co vše se budu muset starat, když si koupím zviŕátko (co vše potřebuje, jak to zajistím, apod.).

- Rozpozná různé modely, které reprezentují tutéž skutečnost.

Informace lze znázorňovat textovou, tabulkovou či grafickou formou. Žáci poznávají různé varianty popisující tutéž skutečnost, např. která část tabulky odpovídá grafickému 
znázornění. Grafická znázornění se opět mohou lišit způsobem zpracování, rozsahem, prioritními položkami. Žáci hledají souvislosti a vyzdvihují podstatu modelu.

\section{Druhý stupeň}

- Vysvětlí rozdíl mezi daty a informacemi; vyhodnocuje data a informace; odhaluje chyby v cizích interpretacích dat.

Žáci se učí z nepřeberného množství dat vybírat data potřebná a zároveň vylučovat data přebytečná či nepodstatná. $Z$ konkrétního souboru dat získávají informace např̀. výpočtem či pochopením souvislostí a následným odvozením nového zjištění. Řešené př́iklady by se měly vztahovat $\mathrm{k}$ různým druhům dat (i nespadající pod informatiku) a informací, např. fyzikální měření teploty - shromažd’ování dat, odstranění zcela chybných položek (např. uvedená denní teplota 100 stupňů Celsia je zjevně špatně zapsaná) a následné získání informací na základě výpočtů, např̀. průměrná denní/noční teplota.

- Při digitalizaci zvolí formát vhodný pro přenos a uchování informací a svou volbu zdůvodní; v prípadě potřeby vhodně kombinuje data různého typu.

Žáci znají jednotlivé formáty konkrétních druhů dat (video, audio, grafika). Ví, jaké mají výhody a nevýhody, tudíž tedy, kdy je dobré daný z nich využít, např. v souvislosti s počtem barev, komprimací nebo velikostí souboru. Sami umí formát souboru změnit bud'to prostřednictvím editoru nebo speciálního programu (např. Format Factory). Rovněž zvládají propojení více formátů $\mathrm{v}$ rámci editorů, např. vložení obrázku do textového souboru nebo vložení zvuku do fotoprezentací.

Další částí je seznámení žáků s omezením využívání jednotlivých druhů dat, tedy s tím, že využívání prř́slušných formátů u dokumentů při posílání mezi uživateli není zcela vhodné, a to proto, že neznáme jeho dostupné programy či operační systém, ke kterým se jednotlivé druhy dat (např. *.doc, *.docx, *.xls) váží. Typickými formáty využívanými pro přenos dat, které nejsou takto spjaty s konkrétními platformami či OS jsou např. CSV a XML.

- Vymezí problém a určí, jaké informace bude potřebovat $\mathrm{k}$ jeho řešení; $\mathrm{k}$ popisu používá grafy, př́ipadně další ikonické modely.

Ze syrových dat je třeba vybírat ta podstatná. Pro větší přehlednost a pochopení souvislostí je možné tato data graficky znázornit podle smyslu, důležitosti jednotlivých dat či dalších požadavků. Nejedná se pouze o klasické sloupcové, výsečové nebo spojnicové grafy, ale také o další modely znázorňující vztahy mezi informacemi pomocí uzlů, např̀. rodokmeny, trasy (nejkratší, nejlevnější, podle způsobu dopravy), potravní řetězce.

- Zhodnotí, zda jsou v modelu všechna data potřebná $\mathrm{k}$ řešení problému; vyhledá chybu v modelu a ve vlastním modelu chybu opraví; porovná svůj navržený model s jinými modely k řešení stejného problému a vybere vhodnější, svou volbu zdůvodní. 
Na druhém stupni žák prohlubuje znalosti v oblasti grafických modelů. Rozumí významu grafů či jiných modelů, které reprezentují informace. Umí vlastními slovy vysvětlit, co model popisuje. Obsažené informace umí převzít a dále využít (napřs. textově, tabulkou).

Žák se orientuje jak ve svém, tak i v cizím modelu vytvořeném na stejném principu. Hodnotí vypovídající schopnost modelu s řešeným problémem, tedy zda model popisuje to, na co se ptáme. Žák porovnává různé typy modelů a vybírá ten, který nejlépe vystihuje danou situaci či objasňuje problém, např̀. v souvislosti s přehledností, obsáhlostí či samotným způsobem prezentace. Typickým př́íkladem může být např. schopnost žáka vybrat $\mathrm{z}$ fyzikálních veličin teplota, čas, hmotnost, objem apod. pouze ty, které potřebuje k výpočtu hustoty. Pro výuku informací lze využít program MS Excel, Access, Office 365, Google Suite nebo iCloud.

\section{Algoritmizace a programování}

\section{První stupeň}

- Přečte textový nebo symbolický zápis algoritmu a vysvětlí jeho jednotlivé kroky.

Pokud chtějí žáci dospět k nějakému výsledku, učí se postupovat určitým způsobem, v určité časové a návazné posloupnosti, např. postup receptu, výměna pneumatiky, co vše je třeba udělat předtím, než přejdu přses silnici, jdu do školy, jdu spát, apod.

- Popíše jednoduchý problém, navrhne a popíše jednotlivé kroky jeho řešení.

Tento bod úzce souvisí s předešlým. Žáci se v rámci algoritmizace neučí jen porozumět vytvořeným postupům, ale vytváŕí své vlastní.

- Upraví připravený postup pro obdobný problém; ověří správnost jím navrženého postupu, najde a opraví v něm př́ípadnou chybu.

Po pochopení smyslu algoritmů žáci hledají chyby související např. se špatným časovým sledem událostí nebo nelogičností $\mathrm{v}$ postupu. Již vytvořené postupy mohou pouze modifikovat a využít $\mathrm{v}$ podobné situaci, např. budou obdobně postupovat při postupu ve frontě na oběd či pro jízdenku. Smyslem je tedy naučit se šetřit svůj čas a již vytvořené algoritmy umět používat $\mathrm{i}$ jinde.

- Rozpozná různé algoritmy, které vedou ke stejným výsledkům, v blokově orientovaném programovacím jazyce sestaví program; program otestuje a opraví $\mathrm{v}$ něm př́padné chyby.

Žáci prostřednictvím této části programují na počítačích, např. ve Scratchi jako zástupci blokově orientovaného programovacího jazyka. Seznamují se s prostředím a principem programování na nových nebo předpřipravených úlohách (např. Hodina kódu, knihovna Scratche, úlohy vytvořené vyučujícím), které jsou často pro malé programátory více motivující. Postupně využívají různé nástroje, učí se, k čemu slouží a jaké jsou mezi nimi rozdíly. Ve svých prográmcích hledají chyby a opravují je tak, aby získali požadovaný výsledek, např. nedokončený čtverec $=>$ špatný počet opakování. Vytvořené algoritmy 
také posuzují a rozhodují se, zda vedou ke stejnému či jinému výsledku, př́ikladem může být opět čtverec a různé způsoby, kterými ho můžeme vytvořit (s/bez př́kazu opakování).

- Rozpozná opakující se vzory, používá opakování a připravené podprogramy, použivá události ke spuštění podprogramů.

Pro rychlost a přehlednost žáci využívají podprogramy, nebo-li bloky, které umožňují opakující se části programu ,schovat" pod jeden nově vytvořený př́kaz, jehož parametry lze následně upravovat. Využijeme to např. při tvorbě různých tvarů (troj-, čtyř-, pěti-úhelník) nebo přesouvání postavičky pomocí jednotlivých kroků.

\section{Druhý stupeň}

- Po přečtení jednotlivých kroků algoritmu nebo programu vysvětlí celý postup, určí problém, který je daným algoritmem řešen.

Druhý stupeň navazuje na problematiku probíranou v nižších trrídách, témata jsou zde probírána do větší hloubky a obtížnosti. Žáci odhalují význam algoritmu bud'to po přečtení textové formy nebo např. také prohlédnutím diagramu popisující vztahy mezi částmi. Zařadit lze praktické využití algoritmů, např. kroky při přechodu přes silnici, tak ale i abstraktnější formy např̀. v podobě matematických a logických operací (různé algoritmické, informatické a logické úlohy dostupné na webu Bobř́ka informatiky (https://www.ibobr.cz/).

- Rozdělí problém na jednotlivé řešitelné části a navrhne a popíše kroky $\mathrm{k}$ jejich řešení.

Žáci mohou bud’to $\mathrm{v}$ programovacím prostředí nebo i jinou formou rozdělovat složitý program na jednodušší části, které řeší postupně, např. programování hry bludiště ve Scratchi (žáci si nejprve uvědomí, co vše hra bude obsahovat, postupně pak programují postavu chodící v bludišti, pozadí a překážky, na které nesmí narazit, získané body a způsob ukončení hry). Pomocí takové či obdobné úlohy si uvědomí, že pokud by si nejprve komplikovanou úlohu nerozškatulkovali, těžko by byli schopni ji nakonec vcelku (díky jednodušším jednotlivým částem) vytvořit.

- Upraví daný algoritmus pro jiné problémy, ověrí správnost postupu navrženého i někým jiným, najde a opraví v něm př́ípadnou chybu.

Žáci se učí šetřit čas i řádky algoritmů jeho generalizací, napřs. vytvořený čtverec mohou přidáním parametru přetvořit na další konkrétní či obecné úhelníky. Svá řešení porovnávají, popisují a rozumí jim (tzn. rozumí jednotlivým príkazům). Správnost mohou testovat i pomocí počítače a programovacího prostředí, kde je zpětná vazba okamžitá (Obr. č. $1)$. 

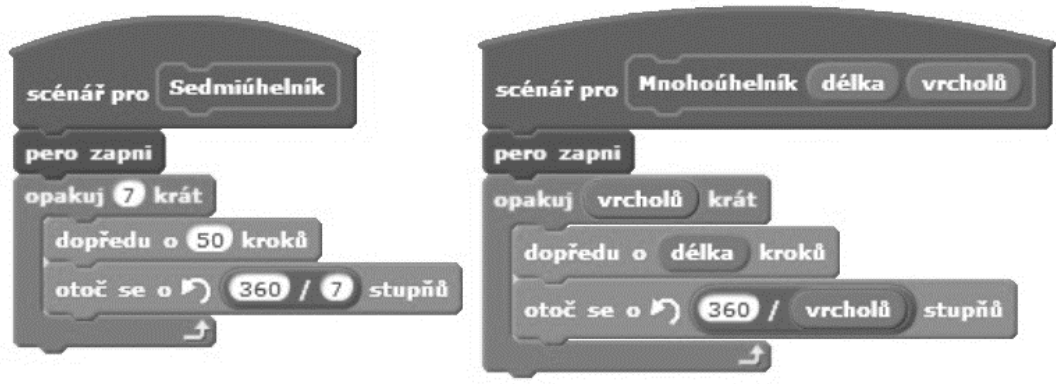

Obr. č. 1: Ukázky vytvoření různých úhelniků pomocí parametrů ve Scratch.

- Navrhne různé algoritmy pro řešení problému, vybere z více možností vhodný algoritmus pro řešený problém a svůj výběr zdůvodní.

V různých situacích můžeme postupovat různě, ale všichni se dostaneme ke stejnému cíli, např. jednoduchý čtverec nebo složitější automat na nápoje můžeme vytvořit různým postupem. Algoritmy se mohou lišit počtem a druhem příkazů, přehledností nebo ošetřením všech variant, které mohou nastat (Obr. č. 2).
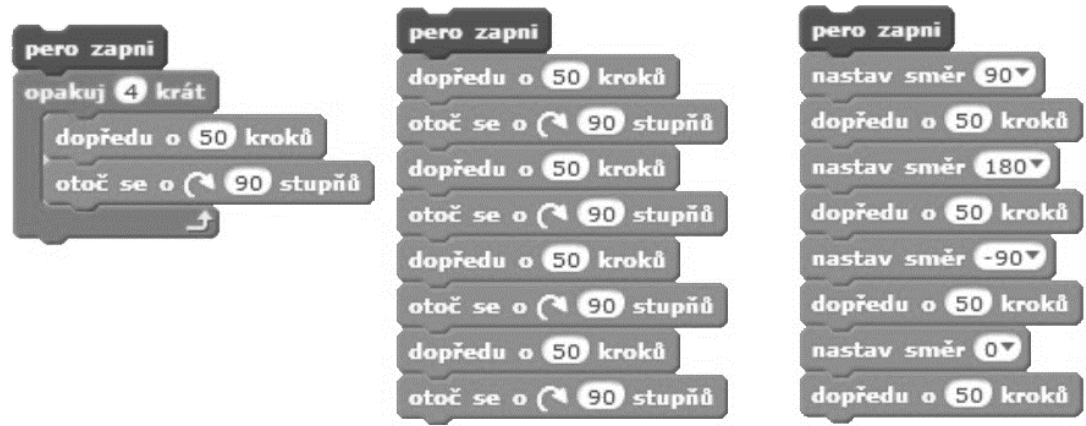

Obr. č. 2: Různé možnosti vytvoření čtverce ve Scratch.

- V blokově orientovaném programovacím jazyce sestaví přehledný program pro vyřešení zadaného problému, program otestuje a opraví v něm prŕípadné logické a běhové chyby.

Běhová chyba znamená kolaps programu (nefunguje), např. zacyklení, dělení nulou. Při logické chybě program běží, ale nedělá to, co žák chce, např. proto, že jsou zadány špatné parametry či logické operace A, NEBO. Pomocí testování, zkoušení a přehodnocování toho, co žák chce, svůj program upravuje. 
- Používá opakování, větvení programu, proměnné, podprogramy s parametry, používá události k paralelnímu spouštění podprogramů.

Pro vytvoření programu žák samozřejmě potřebuje znát jednotlivé príkazy konkrétního programovacího prostředí jako např. opakování, větvení programu (příkazy když), další proměnné, které si vytváŕí, podprogramy (bloky ve Scratchi) s parametry, které využívá pro konkretizaci či obdobné situace a různé způsoby spuštění programu (např. vše spustí najednou, postupně, tlačítkem, myší).

Hojně využivaným prostředím je blokově orientovaný Scratch, dále Tynker, Hodina kódu, lze využít stavebnice Lego WeDo, Mindstorms Lego nebo např. robota Ozobot.

\section{Informační systémy}

\section{První stupeň}

- $\quad \mathrm{V}$ přirozených systémech rozezná jednotlivé prvky a vztahy mezi nimi.

Žáci se seznamují s prvky běžně využívaných informačních systémů, např. co vše obsahuje a jak funguje jídelna, obchod, škola, platba kartou, přihlášení do hry. V této části se rovněž zabývají tím, jak spolu jednotlivé prvky kooperují a závisí na sobě.

- Tř́íí a řadí objekty podle různých kritérií.

Jednotlivé prvky systémů spadají v žebříčku hierarchie na různý stupeň. Žáci rozlišují nadřazenost a podřazenost prvků, jejich důležitost a význam, odlišné a podobné prvky v rámci konkrétních běžně se vyskytujících entit, např. druhy dopravy (letecká, vodní, pozemní) => konkretizace doprav (letecká - helikoptéra, letadlo, rogalo, vodní - člun, parník) $=>$ konkretizace strojů (letadlo - dopravní, vojenské). Dalším př́íladem může být napřr. rozdělení zvířat nebo rostlin.

- Pro vymezený problém zaznamenává do existující evidence číselná i nečíselná data; identifikuje chyby v evidovaných datech a navrhne opravu.

Žáci zpracovávají data do tabulek, např. v rámci výše zmiňované jídelny se může jednat o seznam obědů, den výdeje, počet vyrobených obědů, vydaných obědů, cena za oběd, jména strávníků, kde v některých př́padech zapisují číselná data (cena, počet) a jindy nečíselná (druh obědu, den vydání). Rozumí významu dat, tedy i ví, jaká data do tabulky nepatří, např. uvedení textové hodnoty místo číselné (následně nelze provést žádný výpočet). Dále se zde může jednat i o duplikaci dat (v našem př́padě by byl omylem nějaký oběd uveden vícekrát nebo je zde možnost více strávníků se stejným jménem, žáci tedy přemýšlejí nad jiným identifikačním označením tak, aby za oběd platila vždy správná osoba). Jedná se tedy o úplné základy databázových systémů. 


\section{Druhý stupeň}

- Vysvětlí účel informačních systémů, které používá a identifikuje jejich jednotlivé systémové prvky a vztahy mezi nimi.

Žáci se zabývají informačními systémy, které je obklopují a které běžně využívají, např. Bakaláři, správa tř́́dy (Google Classroom, Microsoft Classroom, Apple Classroom), jízdní rády. Vědí, že tyto systémy se skládají z různých částí a ty na sobě závisejí, různé prvky mají různý význam, uživatelé mohou mít různá práva, apod. Vztahy prvků zakreslují do diagramů.

- Vyhledává, vkládá, upravuje data přes uživatelské rozhraní, řadí a filtruje záznamy v tabulce, využívá při práci s daty v tabulce vzorce a funkce.

Žáci se prakticky seznamují s některými druhy informačních systémů, ve kterých pracují (vyhledávají či vkládají data). Dále tato část zahrnuje práci s tabulkovým procesorem. Žáci pracují prostřednictvím např. MS Excel, Tabulky Google nebo Open Office Calc. Vkládají a formátují data do tabulek, následně provádějí výpočty pomocí matematických operací (např. sčítání, odčítání, dělení, násobení, mocnina) a funkcí (např. když, a, suma, count). Data v tabulkách vyjadřují graficky pomocí grafư (výsečový, sloupcový, spojnicový, bodový).

- Vymezí problém a určí, zda při jeho řešení využije evidenci dat.

Žáci nezpracovávají pouze zadaná, předem připravená data, ale vymýšlí a řeší vlastní návrhy. Navrhují vlastní tabulky a způsob záznamu důležitých položek.

- $\quad$ Nastaví pravidla pro práci se záznamy v evidenci dat.

Do tabulky s evidencí dat, např. zboží, náklady na dopravu, spotřeba paliva, atd., žák vkládá vzorce, které vypočtou požadované sloupečky, např. celková cena prodaného zboží, množství zboží, celkové náklady, zisk, apod.

- Navrhne a vytvoř́ tabulku pro evidenci dat.

Žáci v tabulkovém procesoru vytváří tabulky podle zadání či vlastního uvážení tak, aby byly správně strukturované, smysluplné, přehledné a bez zbytečného opakování některých částí.

- Vede navrženou evidenci dat, sleduje dodržování stanovených pravidel a postupů, hodnotí fungování evidence, opraví chyby, príípadně navrhne vylepšení.

Komplexní úkol zahrnující všechny předešlé části tohoto vzdělávacího okruhu. Žáci vedou svojí vlastní evidenci dat se vším, co je potřeba, např. jejich př́ijmy a náklady, známky, atd. 


\section{Počítač a jeho ovládání}

\section{První stupeň}

- Pojmenuje jednotlivá digitální zařízení, se kterými pracuje, vysvětlí, k čemu slouží.

Žáci znají a umí využívat běžně používaná digitální zařízení, např. fotoaparát, kamera, počítač, mobilní telefon, televize, chytré hodinky, atd.

- Zaznamená, zobrazí, uloží, přenese, vytiskne data.

Žáci umí manipulovat s vytvořenými daty prostřednictvím správce souborů, kde ukládají, kopírují, přesouvají, mažou své soubory a složky, v jejichž hierarchii a způsobu uchovávání mají přehled. Vytvořené soubory tisknou pomocí konkrétních programů, ví jak nastavit tisk (počet a výběr stran, výběr tiskárny). Seznamují se s různými druhy úložných zařízení, např. externí disk, lokální disk, flash disk, sítový disk).

- Rozlišuje operační systém, předinstalované a další aplikace.

Žáci si objasňují význam operačního systému v počítači, využívají základní aplikace (např. kalkulačka, poznámkový blok), které mohou využívat $\mathrm{k}$ běžné práci. $\mathrm{V}$ souvislosti $\mathrm{s}$ dalšími probíranými tématy RVP využívají nástroje dalších programů.

- Přri práci využívá ovládací prvky a nástroje OS, grafického uživatelského rozhraní a pracovní nástroje vybraných aplikací.

Žáci se prakticky orientují ve významu ikon, znají základní funkce operačního systému (práce v hlavním panelu, menu, nastavení plochy, Průzkumník).

- Rozezná způsob propojení digitálních zařízení.

Žáci se učí propojovat různá digitální zařízení zmiňovaná výše různými dostupným i formami, např. kabelem, bezdrátově. Seznamují se s výhodami a nevýhodami různých způsobů, popřípadě různými druhy kabelů podle konkrétních zařízení či bezdrátových možností v podobě Bluetooth, Wifi, apod.

- Propojí digitální zařízení, $\mathrm{k}$ digitálním datům přistupuje i na vzdálených počítačích a spouští online aplikace.

Žáci používají cloudové služby, např. Google Suite, OneDrive či Office 365, kde ukládají svá data a přistupují $\mathrm{k}$ nim jednoduše doma i ve škole. Učí se rozdíl mezi nainstalovanou a online aplikací (např. v souvislosti s místem na disku, ukládáním dat, způsobem spuštění).

- Rozezná nestandardní chování digitálních zařízení a požádá o pomoc. 
Žák v př́ípadě vyskočení okna hlásící chybu nebo nefunkčnosti zařízení ví, že toto chování není standardní. Vyhledá pomoc dospělého, v jednodušších př́ípadech (např. vybití zařízení, potřeba vložení externí pamětové karty) situace řeší sám.

- Dodržuje řád a pravidla stanovená pro práci s digitálními technologiemi. Respektuje bezpečnostní nastavení digitálních zařízení, se kterými pracuje, rozezná podezřelé situace a informace na internetu a požádá o pomoc dospělou osobu.

Žáci dodržují hygienická i ergonomická pravidla při využívání digitálních technologií. Využivají doporučená nastavení a funkce digitálních zařízení, která znají tak, aby nepoškodili jejich funkčnost. V rámci sdílení a výměny informací prostřednictvím e-mailu, sociálních sítí, chatu, internetových diskuzí, cloudu a dalších možností internetu se chovají obezřetně. To znamená, že znají rizika spojená s anonymitou uživatelů či dezinformacemi, které po webových stránkách kolují.

- Vysvětlí rozdíly identity ve fyzickém a digitálním světě, vybírá informace, které o sobě může zveřejnit.

Žáci se v prostředí digitálního světa chovají bezpečně, nezveřejňují o sobě žádné osobní informace, nenavštěvují stránky s nevhodným obsahem, dávají si pozor na nepravdivé informace, udržují si odstup od jiných anonymních uživatelů, jejichž opravdovou totožnost neznají.

Porovnávají své fyzické a digitální já - odlišnosti, možnosti, rozdíly těchto dvou světů, které mohou být $\mathrm{v}$ některých př́padech ku prospěchu, $\mathrm{v}$ jiných právě naopak. Jedná se více o výchovné, než-li vzdělávací téma, velice důležitý je způsob předání a kladné zapůsobení na povědomí dítěte.

- Uvádí př́klady využití digitálních technologií v různém kontextu, zhodnotí výhody využití jednotlivých digitálních zařízení pro svou práci.

Digitální technologie jsou dnes naší každodenní součástí, využiváme je napřs. ve vzdělávání, zaměstnání, v nemocnicích, na cestách $\mathrm{v}$ autě, pro zábavu nebo díky nim můžeme v mnoha př́padech hodně usnadnit život hendikepovaných lidí. Na druhou stranu se v některých př́padech lze obávat masových médií, digitálních zbraní nebo obrovské možnosti rychlé komunikace $\mathrm{v}$ oblasti zločinu či terorismu. Žáci v rámci této části poznávají digitální technologie i z jiné perspektivy než pouze jako prostředek pro ukrácení dlouhé chvíle, pořízení fotografie z dovolené nebo napsání referátu do školy.

\section{Druhý stupeň}

- Určí charakteristické parametry počítačů v různých zařízeních i typických částí počítačových soustav.

Žáci nahlížejí pod pokličku digitálních zařízení. Nezabývají se pouze jejich ovládáním, ale i parametry a funkčními vlastnostmi, např. druhy pamětí, grafické karty, procesory (např. v souvislosti s principem, velikostí, využitím). 
- Využivá paměti, běžná vstupní a výstupní zařízení počítačových soustav.

Žák ukládá a zpětně načítá data z různých úložných zařízení, např. $\mathrm{CD}, \mathrm{DVD}$, flash disk, externí disk, lokální disk, cloudové služby. Při práci efektně využívá vstupní (myš, klávesnice, skener, mikrofon) i výstupní (tiskárna, monitor, reproduktory) zařízení. Periferie také sám připojuje, např. kabelem či bezdrátově.

- Popíše typické úkoly OS jako prostředníků mezi uživatelem a počítačem.

Žáci se zabývají zpracováváním informací v počítači, početními operacemi, které vykonává procesor, principem řazení jednotlivých úkonů, které počítači zadávají nebo multitaskingem.

- Cíleně přizpůsobí uživatelské prostředí osobním potřebám, použije odpovídající si nástroje v různých aplikacích.

Žáci si přizpůsobují pracovní plochu svým vlastním potřebám a prioritám, např. nastavují plochu, hlavní panel, widgety, hierarchii složek a souborů na disku. Instalují potřebné aplikace pro jejich práci, v jejíchž nástrojích se orientují.

Vědí, že ke stejným účelům mohou pro svou práci využít různé nástroje a programy, např. různé druhy správce souborů (Průzkumník, Total Commander), grafické programy (Malování, Zoner Photo Studio, Corel PhotoPaint), textové (Poznámkový blok, MS Word, Dokumenty Google).

- Uvede př́klady sítí a popíše jejich charakteristické znaky, vybírá nejvhodnější způsob k připojení digitálních zařízení do počítačové sítě.

Žáci jsou celou dobu práce $\mathrm{v}$ počítačových učebnách součástí počítačové sítě. $\mathrm{V}$ této části se zabývají jejich smyslem, využitím, velikostmi, druhy, rozdíly oproti využívání lokálního počítače. Seznamují se s různými typologiemi sítí, výhodami (nevýhodami) jejich využívání a možnostmi propojení (switch, router). Kromě praktického zapojení a využití sítí se učí i princip fungování přenosu informací mezi počítači, způsob přihlášení na svůj účet, možnosti nastavení práv, atd.

- Nastavuje oprávnění pro př́stup ke sdíleným datům ze vzdálených počítačů i z online aplikací.

Žáci sdílejí dokumenty i jiné soubory s dalšími uživateli proto, aby mohli pracovat společně a rychleji. Při využívání cloudových služeb (Googe Suite, Office 365, iCloud, OneDrive) nastavují možnosti úprav dalším uživatelům, např. pouze prohližení, psaní komentárù, úpravy.

- Poradí si s typickými závadami a chybovými stavy počítačů.

Žáci sami řeší běžně vyskytující se problémy, např. pomocí vypnutí neběžící aplikace přses správce úloh; opětované připojení $\mathrm{k}$ internetu. 
- Vysvětlí možnosti a omezení technických a programových zabezpečovacích řešení a dokáže usměrnit svoji činnost tak, aby minimalizoval riziko ztráty či zneužití dat.

Žáci si nastavují bezpečná hesla, znají zabezpečující základy šifrování dat, chrání svoje data pomocí zálohování. Při sdílení dat nastavují práva tak, aby o své soubory neprrišli. Během pořizování a publikování informací dodržují autorská práva.

Žáci mají pojem o druzích nebezpečného softwaru, využívají antivirové programy, firewall a další preventivní opatření.

- $\quad$ S vědomím odlišnosti mezi fyzickým a digitálním světem vytváří a spravuje svoji digitální identitu.

Žáci na internetu zveřejňují pouze neosobní informace, které nelze následně zneužít. Uvědomují si nebezpečí související s anonymitou uživatelů či možností uvěření informacím, které jsou zcela nepravdivé. Na sociálních sítích potažmo internetu se chovají slušně a opatrně.

- Orientuje se ve vývoji digitálních technologií a popíše, jak změny ovlivnily postupy v běžném životě, u předpokládaných trendů zhodnotí prrínos a rizika změn.

Žáci znají aktuální trendy využití digitálních technologií (vzdělávání, hendikepovaní, práce, zábava, cestování, medicína, věda). Zabývají se i konkrétními změnami při využívání digitálních technologií, např̀. pokladny v obchodě x počítání ručně; lékařství (přístroje), nakupování kartou (online), doprava (letadla, auta - mají v sobě počítač), masová média, velké množství informací na internetu, rychlost komunikace (výhody a nevýhody) - rizika spojená $\mathrm{s}$ dezinformacemi, krádež tajných dat => využití pro špatné účely.

\section{Návrh vzorového ŠVP pro vzdělávací okruh Využití digitálních technologií vzdělá- vací oblasti Člověk a svět práce}

\section{Charakteristika oblasti}

Vzdělávací oblast Člověk a svět práce se zaměruje na rozvíjení schopností a dovedností žáků ve spojitosti s řešením běžně se vyskytujících situací. Žáci se zabývají v rámci různých vzdělávacích okruhů konkrétními lidskými činnostmi, $\mathrm{k}$ jejichž řešení využívají různé druhy techniky. Zaměření předmětu je tvůrčí a praktické proto, aby žáci byli po jeho absolvování schopni samostatně pracovat a řešit problémy důležité $\mathrm{k}$ jejich dalšímu uplatnění.

\section{Návrh časové dotace vzdělávacího okruhu Využití digitálních technologií}

- 6. ročník (Tab. č. 1): 0,5 hodiny týdně (resp. 1 hodina 1 x za 14 dní)

- 8. ročník (Tab. č. 2): 0,5 hodiny týdně (resp. 1 hodina $1 \mathrm{x}$ za 14 dní)

\section{Charakteristika předmětu}

Využití digitálních technologií prohlubuje získané znalosti žáků v oblasti výpočetní techniky. Poskytuje teoretické i praktické dovednosti v oblasti multimédií, tzn. grafiky, audia a videa. Žáci během hodin využívají různé možnosti publikování informací a dat. 


\section{Klíčové kompetence}

Kompetence k učení

- Z Žák vyhledává a třídí informace a na základě jejich pochopení, propojení a systematizace je efektivně využívá v procesu učení, tvưrčích činnostech a praktickém životě.

- Z Žák operuje s obecně užívanými termíny, znaky a symboly, uvádí věci do souvislostí; propojuje do širších celků poznatky z různých vzdělávacích oblastí a na základě toho si vytváří komplexnější pohled na matematické, př́irodní, společenské a kulturní jevy.

Kompetence k řešení problémů

- Z Žák vyhledá informace vhodné k řešení problému, nachází jejich shodné, podobné a odlišné znaky, využívá získané vědomosti a dovednosti k objevování různých variant řešení.

- Z Žák samostatně řeší problémy; volí vhodné způsoby řešení; užívá přri řešení problémů logické, matematické a empirické postupy.

- Z Žák ověřuje prakticky správnost řešení problémů a osvědčené postupy aplikuje při řešení obdobných nebo nových problémových situací, sleduje vlastní pokrok při zdolávání problémů.

Kompetence komunikativní

- Z Žák formuluje a vyjadřuje své myšlenky a názory v logickém sledu, vyjadřuje se výstižně, souvisle a kultivovaně v písemném i ústním projevu.

- Z Žák rozumí různým typům textů, záznamů, obrazových materiálů a jiných informačních a komunikačních prostředků, přemýšlí o nich, reaguje na ně a tvořivě je využívá ke svému rozvoji a k aktivnímu zapojení se do společenského dění.

- Žák využívá informační a komunikační prostředky a technologie pro kvalitní a účinnou komunikaci s okolním světem.

Kompetence sociální a personální

- Ž́a účinně spolupracuje ve skupině.

- Z Žák v prípadě potřeby poskytne pomoc nebo o ni požádá.

- Žák přispívá $\mathrm{k}$ diskusi v malé skupině i $\mathrm{k}$ debatě celé třídy, chápe potřebu efektivně spolupracovat $\mathrm{s}$ druhými při řešení daného úkolu, oceňuje zkušenosti druhých lidí, respektuje různá hlediska a čerpá poučení z toho, co si druzí lidé myslí, ř́kají a dělají.

Kompetence občanská

- Z Žák chápe základní principy, na nichž spočívají zákony a společenské normy, je si vědom svých práv a povinností ve škole i mimo školu.

Kompetence pracovní

- Z Ž́k používá bezpečně a účinně nástroje a vybavení. 


\section{Vzdělávací obsah}

\section{Druhý stupeň}

\section{6. ročník}

\begin{tabular}{|c|c|}
\hline álních technologií & \\
\hline émata: Mediální výchova - Tv & rba mediálních sdělení \\
\hline $\begin{array}{l}\text { Výstupy } \\
\end{array}$ & Učivo \\
\hline $\begin{array}{l}\text { Žák ovládá základní funkce digitální } \\
\text { techniky; diagnostikuje a odstraňuje zá- }\end{array}$ & $\begin{array}{l}\text { Vektorová grafika (princip vektorového } \\
\text { kreslení, výhody/nevýhody, formáty) }\end{array}$ \\
\hline $\begin{array}{l}\text { kladní problémy při provozu digitální } \\
\text { techniky. } \\
\text { Žák propojuje vzájemně jednotlivá digi- }\end{array}$ & $\begin{array}{l}\text { Vektorová grafika (sestavení obrázku } \\
\text { podle zadání, editace, export do různých } \\
\text { formátů) }\end{array}$ \\
\hline $\begin{array}{l}\text { tální zařízení. } \\
\text { Žák ošetřuje digitální techniku a chrání ji }\end{array}$ & $\begin{array}{l}\text { Rastrová grafika (princip rastrového kres- } \\
\text { lení, výhody/nevýhody, formáty) }\end{array}$ \\
\hline & $\begin{array}{l}\text { Rastrová grafika (práce v editoru, úprava } \\
\text { fotografií, export do různých formátů) }\end{array}$ \\
\hline & $\begin{array}{l}\text { 3D grafika (princip 3D grafiky, vý- } \\
\text { hody/nevýhody) }\end{array}$ \\
\hline & $\begin{array}{l}\text { 3D grafika (práce v programu, rendero- } \\
\text { vání) }\end{array}$ \\
\hline & $\begin{array}{l}\text { Digitální fotoaparát (funkce, nas } \\
\text { praktické využívání) }\end{array}$ \\
\hline
\end{tabular}

Tab. č. 1: Návrh ŠVP - využití digitálních technologií v 6. ročníku.

\section{8. ročník}

\begin{tabular}{|c|c|}
\hline \multicolumn{2}{|l|}{ Využití digitálních technologií } \\
\hline \multicolumn{2}{|c|}{ Prưřezová témata: Mediální výchova - Tvorba mediálních sdělení } \\
\hline Výstupy & Učivo \\
\hline \multirow{3}{*}{$\begin{array}{l}\text { Žák ovládá základní funkce digitální tech- } \\
\text { niky. } \\
\text { Žák pracuje uživatelským způsobem s } \\
\text { mobilními technologiemi. }\end{array}$} & $\begin{array}{l}\text { Tvorba webových stránek (zásady tvorby } \\
\text { stránek a prezentování informací na inter- } \\
\text { netu) }\end{array}$ \\
\hline & $\begin{array}{l}\text { Tvorba webových stránek ve WYSIWYG } \\
\text { editoru (text, menu, obrázky, odkazy, vi- } \\
\text { dea) }\end{array}$ \\
\hline & Webové stránky - možnosti publikování \\
\hline \multirow{4}{*}{$\begin{array}{l}\text { Žák ovládá základní funkce digitální tech- } \\
\text { niky. } \\
\text { Žák diagnostikuje a odstraňuje základní } \\
\text { problémy při provozu digitální techniky. } \\
\text { Žák ošetřuje digitální techniku a chrání ji } \\
\text { před poškozením. }\end{array}$} & $\begin{array}{l}\text { Digitální kamera (funkce, nastavení, prak- } \\
\text { tické využívání) }\end{array}$ \\
\hline & $\begin{array}{l}\text { Střih videa (práce v editoru, využití něko- } \\
\text { lika stop, efekty, formáty, export) }\end{array}$ \\
\hline & $\begin{array}{l}\text { Mikrofon, reproduktory (nastavení, připo- } \\
\text { jení) }\end{array}$ \\
\hline & $\begin{array}{l}\text { Střih zvuku (práce v editoru, stopy, efekty, } \\
\text { formáty, export) }\end{array}$ \\
\hline
\end{tabular}

Tab. č. 2: Návrh ŠVP - využití digitálních technologií v 8. ročníku. 


\section{Závěr}

Informatika je v novém RVP vnímána nikoliv jako obsluha počítače, ale jako obor všeobecného vzdělávání, rozvíjející mentální a kognitivní vlastnosti jedince, podobně jako to dělá matematika a prírodní vědy (Vaníček, 2018).

V rámci výuky ICT se po uvedení nového RVP pro základní vzdělávání v oficiální platnost budou učitelé zabývat především programováním, algoritmizací, logikou v podobě tvorby modelů nebo informačních systémů. Rozšíření je také v zaměření na různé druhy digitálních technologií, které od vydání minulého RVP v r. 2005 značně pokročily.

Jelikož je množství informatických témat daleko rozsáhlejší než doposud a některá aktuální témata v novém RVP obsažená nejsou, kromě již publikovaného vzorového ŠVP (Pexa; Čapková, 2018) jsme vytvořili i návrh ŠVP pro vzdělávací okruh Využití digitálních technologií (vzdělávací oblast Člověk a svět práce), naplněný zejména tvorbou a zpracováním multimédií, tvorbou webových stránek a rastrovou, vektorovou či 3D grafikou.

ŠVP bývají většinou obecnějšího charakteru, a to proto, aby nevznikala nutnost jejich úprav při každé drobnější výukové změně, např. ve spojitosti s využitím jiného softwaru nebo učebních pomůcek. Přesto je ale pro začínající i zkušenější učitele podstatné, jaké programy lze využívat či jaká podtémata a typy úloh zařadit do výuky. Konkretizujeme tedy jednotlivé výstupy navrženého ŠVP a tyto návrhy jsou podpořeny několika videohospitacemi, ve kterých je názorně předvedena výuka aktuálních informatických témat - programování v prostředí Scratch, využití robotiky, cloudových služeb a tvorba webových stránek.

Návrh vzorového ŠVP úzce souvisí s významnou proměnou výuky informatiky, tedy přechodem od uživatelských dovedností a mechanického ovládání převážně kancelářských softwarových produktů k tvůrčí činnosti žáků a studentů, k př́íklonu k algoritmizaci, programování, modelování a informačním systémům, tedy tématům, která v původním RVP vůbec obsažena nebyla. Naše návrhy tedy budou v blízké budoucnosti velmi užitečné autorům nových ŠVP na základních školách a víceletých gymnáziích, resp. se jimi školy mohou v budoucnu inspirovat.

Od konce r. 2018 se již výuka podle nových programů testuje ve vybraných 70 základních školách České republiky, a když testování proběhne bez problémů, od školního roku 2021/2022 by měly být nové vzdělávací plány pro informatiku závazné pro všechny základní školy.

K úspěšnému přechodu na zcela nový typ výuky by mohly učitelům výrazně pomoci nové učebnice informatiky, které byly vytvořeny v rámci projektu Podpora rozvíjení informatického myšlení (PRIM, RČP: CZ.02.3.68/0.0/0.0/16_036/0005322). Tento strategický projekt vypsaný MŠMT má za cíl připravit půdu pro změnu zaměření školního informatického vzdělávání na všech stupních škol směrem k výuce algoritmizace, informatického myšlení, s odklonem od uživatelského přístupu k počítači. Př́ijemcem projektu je Pedagogická fakulta Jihočeské univerzity, partnery projektu jsou všechny pedagogické fakulty v ČR a Národní ústav pro vzdělávání. Veškeré informace včetně betaverzí učebnic lze nalézt na portálu imysleni.cz.

\section{Literatura}

Acer: International Computer and Information Literacy Study [online] (2018). [cit. 201806-29]. Dostupné z: https://icils.acer.org/.

Bělecký, Z. (2007). Klíčové kompetence v základním vzdělávání. Praha: Výzkumný ústav pedagogický. 
European Commission. (2017). DigComp 2.0: The Digital Competence Framework for Citizens [online]. [cit. 2017-07-15]. Dostupné z: https://ec.europa.eu/jrc/en/publication/eur-scientific-and-technical-research-reports/digcomp-20-digital-competence-framework-citizens-update-phase-1-conceptual-reference-model.

Ferrari, A. (2012). Digital Competence in Practice: An Analysis of Frameworks [online]. European Commission, Institute for Prospective Technological Studies. Dostupné z: ftp.jrc.es/EURdoc/JRC68116.pdf.

Charalambidis, A. (2005). Manuál pro tvorbu školních vzdělávacich programů v základním vzdělávání. Praha: VúP.

Info.edu.cz: Portál o školství a vzdělávání [online] (2010). [cit. 2018-01-20]. Dostupné z: http://info.edu.cz/.

Kalaš, I. (2013). Premeny školy v digitálnom veku. Slovenské pedagogické nakladatel'stvo - Mladé letá.

Lessner, D. (2014). Analýza významu pojmu „computational thinking“. In: Journal of Technology and Information Education, 6 (1), Olomouc, pp. 71-88. Dostupné z: http://www.jtie.upol.cz/pdfs/jti/2014/01/06.pdf.

Metodický portál RVP.cz [online]. (2012). Praha [cit. 2018-01-24]. Dostupné z: http://rvp.cz/.

MŠMT. (2005). Rámcový vzdělávaci program pro základni vzdělávání. Praha: VÚP. MŠMT. (2007). Rámcový vzdèlávaci program pro gymnázia. Praha: VÚP.

MŠMT. (2016). Rámcový vzdělávaci program pro základni vzdělávání. Praha: MŠMT.

Národní ústav pro vzdělávání. (2018). Revize RVP v oblasti Informatiky a informačnich a komunikačních technologii [online]. Praha [cit. 2018-01-24]. Dostupné z: http://www.nuv.cz/ revize-rvp-ict.

Pedagogické.info [online]. (2007). [cit. 2017-06-29]. Dostupné z: http://www.pedagogicke.info/.

Pexa, P., Čapková, M. (2018). Inovace RVP a ŠVP v závislosti na aktuálních trendech výuky ICT na ZŠ (Innovation of the FEP and SEP according to the present trends of ICT education in primary schools). Journal of Technology and Information Education, Olomouc - EU, Univerzita Palackého, 10 (2).

Respekt. (2018). Začiná revoluce ve výuce informatiky [online]. Respekt [cit. 2018-08-31]. Dostupné z: https://www.respekt.cz/.

Schubert, S., Schwill, A. (2011). Didaktik der Informatik. Switzerland: Springer Nature. Vaníček, J. (2018). Jak budou vypadat a kde se vezmou učebnice informatiky podle nových $R V P$ [přednáška]. Nové Město na Moravě: Gymnázium Vincence Makovského, 27.-29. 3. Vlčková, K. (2005). Nová struktura kurikulárních dokumentů v ČR [online]. [cit. 2017-0629]. Dostupné z: https://is.muni.cz/el/1411/jaro2005/MFPE0821/um/struktura kurikularnich dokumentu cr.pdf?lang=cs. 